\title{
A história social sul-africana dos anos 1980 e a obra de E. P. Thompson: o caso do Wits History Workshop
}

\author{
The 1980s South African Social History and E. P. Thompson's \\ Works: The Case of the Wits History Workshop
}

Francisco Macedo*

Resumo: O artigo analisa a história social sul-africana dos anos 1980 , centrando-se na produção do Wits History Workshop (WHW), instituição amplamente reconhecida como o principal polo produtor e difusor da nova abordagem historiográfica no país. Além de ressaltar as condições de emergência, as principais temáticas e os eixos analíticos recorrentes da história social sul-africana dos anos 1980, o artigo destaca, também, a centralidade da obra de E. P. Thompson nessa produção, particularmente naquela vinculada ao WHW.

Palavras-chave: História Social; África do Sul; E. P. Thompson.

Abstract: The article analyses the 1980s South African social history, focusing on the Wits History Workshop's (WHW) production, institution largely recognized as the main diffusion and production center of the new historiographical approach in the country. Besides pointing out conditions of emergence, crucial themes, and recurrent analytical axis of the 1980s South African social history, the article also highlights the centrality of E. P. Thompson's works in this production, especially in that one related to the WHW.

Keywords: Social History; South Africa; E. P. Thompson.

$\mathbf{N}$ ADÉCADADE 1980, a história social sul-africana-também chamada de "historiografia radical", "historiografia revisionista" e "historiografia neomarxista" nos estudos historiográficos do país - experimentou o que é frequentemente caracterizado como uma espécie de "era de

Doutor em História pela Universidade de São Paulo (USP). Professor do Instituto Federal de Minas Gerais (IFMG) - Campus Santa Luzia, ao qual agradeço pelas condições de realização da pesquisa de pós-doutorado, que desenvolvo sob a supervisão do Prof. Dr. Antonio Luigi Negro na Universidade Federal da Bahia (UFBA), e da qual este artigo é um produto. E-mail: francisco.macedo@ifmg.edu.br. ORCID: https://orcid.org/0000-0002-9757-7652. 
ouro". ${ }^{1}$ Para fundamentar tal avaliação, mobiliza-se, quase sempre, uma grande diversidade de indicadores, tais como: o crescimento da quantidade de pesquisadores praticantes da abordagem, os concorridos congressos de historiadores sociais, a multiplicação dos temas/ objetos relativos ao campo, a proliferação de publicações na área e, até mesmo, a notável sintonia dessa produção acadêmica com as lutas sociais pelo fim do Apartheid, que então engajavam amplos setores da população da África do Sul. ${ }^{2}$

Entre as várias instituições universitárias de produção historiográfica responsáveis por esse boom de estudos de história social na África do Sul, o History Workshop, situado na University of the Witwatersrand (Joanesburgo), é, recorrentemente, apresentado como o mais importante polo produtor/difusor da abordagem que, ao longo dos anos 1980, viria a se tornar hegemônica na historiografia sul-africana. ${ }^{3}$ Criado, em 1977, por professores de diferentes departamentos de ciências sociais e humanas da University of the Witwatersrand (daqui por diante, Wits), o grupo de pesquisa (convertido em centro de estudos nos anos 1980) mostrou-se diverso desde sua fundação, reunindo historiadores, sociólogos, antropólogos, cientistas políticos, teóricos da literatura, educadores etc. Desde seus anos iniciais, mas de modo mais explícito ao longo dos anos 1980, o Wits History Workshop (daqui por diante, WHW) delineou os elementos centrais que orientariam a atuação da instituição, destacando-se entre seus objetivos mais amplos: a) produzir e promover uma historiografia materialista marcada pela análise de classe e pela abordagem da "história vista de baixo", privilegiando a vida cotidiana, as experiências, as lutas e as formas de consciência das "pessoas comuns"; b) priorizar a história dos sul-africanos negros, negligenciada, anteriormente, em explicações racialmente enviesadas do passado; c) tornar a pesquisa acadêmica produzida nos termos anteriormente mencionados disponível para um público não universitário (especialmente, organizações de trabalhadores, associações comunitárias e entidades estudantis); ${ }^{4}$ d) descolonizar a historiografia sul-africana, o que seria feito, especialmente, por meio de uma intensa pesquisa

1 O termo é utilizado por SAUNDERS, C. South African Historical Writing to The End of the Apartheid Era. Oxford Research Encyclopedia of African History, 2018. Disponível em: https://bit.ly/2UvcSi5. Acesso em: 18 abr. 2019.

2 Cf., por exemplo, NASH, A. The Moment of Western Marxism in South Africa. Comparative Studies of South Asia, Africa and the Middle East, v. 19, n. 1, p. 66-82, 1999; COBLEY, A. Does Social History Have a Future? The Ending of Apartheid and Recent Trends in South African Historiography. Journal of Southern African Studies, v. 27, n. 3, p. 613-625, 2001.

3 Cf. MURRAY, M. J. The Triumph of Marxist Approaches in South African Social and Labour History. Journal of Asian and African Studies, v. 23, n. 1-2, p. 79-101, 1988; BONNER, P. New Nation, New History - The History Workshop in South Africa, 1977-1994. The Journal of American History, v. 81, n. 3, p. 977-985, 1994.

4 Nos anos 1980, a atuação do WHW no campo da história pública desdobrou-se em várias frentes de ação. Nos congressos acadêmicos organizados pela instituição, havia um dia reservado para a interação entre estudiosos e integrantes das mais variadas organizações da sociedade civil, contando com apresentações de fotografias, exibições de filmes, montagens de peças teatrais, palestras etc. Os chamados Open Days chegaram a reunir milhares de pessoas. O WHW implementou, também, projetos de história oral, como o Write Your Own History, responsável pelo treinamento de pessoas comuns para escreverem as histórias de suas próprias comunidades e sindicatos. Outra forma de atuação no campo da história pública foram as publicações especialmente voltadas para uma audiência não especializada. Para mais informações, Cf. CALLINICOS, L. Popular History in the Eighties. Radical History Review, n. 46-47, p. 285-297, 1990; WITZ, L. The Write Your Own History Project. Radical History Review, n. 46-47, p. 377-387, 1990; ANTHONY, D. South African People's History. Radical History Review, n. 46-47, p. 411-419, 1990. 
em fontes locais (com largo uso de história oral ${ }^{5}$ e forte ênfase em história local/regional ${ }^{6}$ ), rompendo com esmagadora participação, na pesquisa historiográfica sobre a África do Sul, de estudiosos situados em universidades estrangeiras (especialmente, britânicas). ${ }^{7}$ Crucial para a implementação de tais objetivos (e, de certo modo, tomada, também, como uma meta permanente da instituição) foi a realização, a partir de 1978, de congressos trienais que, organizados pelo comitê diretivo do WHW, tornaram-se o mais importante evento acadêmico para os historiadores sociais na África do Sul nos anos 1980 e reuniram pesquisadores, ativistas, professores da educação básica e membros das mais variadas organizações da sociedade civil, evidenciando as fortes conotações políticas da produção historiográfica apresentada e debatida nos eventos promovidos pelo WHW. ${ }^{8}$

Nos próprios termos em que o WHW expressou seus objetivos, é possível vislumbrarmos a marcante presença do vocabulário frequentemente associado à obra do historiador inglês Edward Palmer Thompson (1924-1993). Em algumas ocasiões, a importante influência do pensamento thompsoniano foi abertamente sublinhada por membros do WHW. Deborah Posel, uma ex-integrante da instituição, por exemplo, afirma que:

A maior parte do trabalho que foi publicado sob a rubrica do WHW estava articulado por meio da linguagem de classe - como uma espécie de senso comum teórico, com pouca inclinação para declarar abertamente suas bases conceituais ou epistemológicas. No núcleo intelectual da organização, a marca da abordagem de Thompson para o estudo da agência de "pessoas comuns" era evidente. Nos primeiros anos do WHW, essa posição foi explicitada. 9

Jonathan Hyslop, outro ex-membro do WHW, também não hesitou em asseverar que a obra de Thompson "teve um enorme impacto na escrita da história na África do Sul, começando nos anos 1970, alcançado seu auge nos anos 1980 e começo dos 1990, e estendendo-se até o presente". ${ }^{10}$ Indo além, Isabel Hofmeyr, outra ex-integrante do WHW, mostrou-se taxativa ao

5 Para uma reflexão crítica sobre os usos da história oral na produção do WHW, cf. HOFMEYR, I. "Wailing for Purity": Oral Studies in Southern African Studies". African Studies, v. 54, n. 2, p. 16-31 1995.

6 Para os diferentes significados que o termo "local" assumiu ao longo da história do WHW, cf. NIEFTAGODIEN, N. The Place of "The Local" in History Workshop's Local History. African Studies, n. 69, v.1, p. 41-61, 2010.

7 Para a caracterização anterior (isto é, os itens de "a" a "d"), cf. o cap. 2 ("The History Workshop, Marxist Social History and South African Historiography") de TATHAM, G. K. The University of the Witwatersrand History Workshop and Radical South African Historical Scholarship in the 1970s and 1980s. (Master's Degree) - University of Cape Town, Cape Town, 1992, p. 55-98.

8 Cf. BOZZOLI, B. Intellectuals, Audiences, and Histories: South African Experiences, 1978-1988. Radical History Review, n. 46-47, p. 237-263, 1990. Vale acrescentar que, a partir de uma seleção dos papers apresentados nos congressos trienais, o comitê diretivo do WHW organizou a publicação de cinco livros, os quais constituem uma das mais consistentes amostras da história social sul-africana dos anos 1980: BOZZOLI, B. (ed.). Labour, Townships and Protest. Johannesburg: Ravan, 1979; BOZZOLI, B. (ed.). Town and Countryside in the Transvaal: Capitalist Penetration and Popular Response. Johannesburg: Ravan, 1983; BOZZOLI, B. (ed.). Class, Community, and Conflict: South African Perspectives. Johannesburg: Ravan, 1987; BONNER, P. et al. (ed.). Holding Their Ground: Class, Locality, and Culture in 19th and 20th Century South Africa. Johannesburg: Ravan, 1989; BONNER, P. et al. (ed.) Apartheid's Genesis: 19331962. Johannesburg: Ravan, 1993.

9 POSEL, D. Social History and the Wits History Workshop. African Studies, v. 69, n. 1, 2010, p. $33-34$ (grifos nossos).

10 HYSLOP, J. E. P. Thompson in South Africa: The Practice and Politics of Social History in an Era of Revolt and Transition, 1976-2012. International Review of Social History, n. 61, 2016, p. 96. 
assegurar que a "influência poderosa exercida por The Making na vida intelectual sul-africana está além de qualquer questionamento. A história social de estilo thompsoniano inspirou um movimento de 'história vista de baixo' que, por sua vez, alimentou a arte, a dramaturgia, a história pública e programas de educação de trabalhadores e de adultos". ${ }^{11}$ Em evento relativamente recente, em celebração das mais de três décadas do WHW, atuais dirigentes da instituição não deixaram de assinalar a persistência do legado thompsoniano, lembrando que, tanto na academia ocidental quanto na sul-africana, a história social foi animada por "um forte projeto normativo enraizado em uma versão 'humanista' do marxismo na tradição de E. P. Thompson. (...) É nessa tradição de história social como 'história a partir de baixo' que o $H W$ tem suas origens". ${ }^{12}$

O destacado lugar da obra thompsoniana na história social sul-africana dos anos 1980, especialmente na produção vinculada ao $W H W$, foi apontado não apenas por membros da organização, mas também por historiadores estabelecidos em outras instituições do país. ${ }^{13}$ Certamente, sua notável influência não se limitava, naquele período, à África do Sul, podendo ser percebida na produção historiográfica de outras nações do continente ${ }^{14} \mathrm{e}$ de diversos outros países do mundo. ${ }^{15}$ Permaneçamos, contudo, na África do Sul, onde, no continente africano, teriam sido produzidos, segundo Cooper, os engajamentos mais sistemáticos e consistentes com aspectos centrais da obra do historiador inglês ${ }^{16}$ e procuremos entender mais de perto as condições que, nos anos 1970 e 1980, possibilitaram a emergência e a consolidação da história social (particularmente, a de matriz thompsoniana) como principal abordagem no interior da historiografia sul-africana.

11 HOFMEYR, I. South African remains: E. P. Thompson, Biko and the limits of The Making of the English Working Class. Historical Reflections, v. 41, n. 1, 2015, p. 100.

12 LISSONI, A.; NIEFTAGODIEN, N. and ALLY, S. Introduction - Life after Thirty Colloquium (History Workshop) A Critical Celebration. African Studies, v. 69, n. 1, 2010, p. 3-4. Para dois artigos recentes em que ex-membros do WHW procuram problematizar e relativizar a centralidade da obra de E. P. Thompson na produção filiada à instituição, cf. DELIUS, P. E. P. Thompson, "Social History", and South African Historiography, 1970-90. Journal of African History, v. 58, n. 1, p. 3-17, 2017; GLASER, C. Thompson on the Highveld? Social History and Humanist Socialism in South Africa in the 1980s and Early 1990s. Social History, v. 45, n. 4, p. 427-439, 2020.

13 Cf., por exemplo, MINKLEY, G. Re-examining Experience: The New South African Historiography. History in Africa, v. 13, p. 269-281, 1986; SPARKS, S. The Peculiarities of South African History: Thompsonian Social History and the Limits of Colonialism. Social History, v. 45, n. 4, p. 440-452, 2020; MOODIE, T. D. Using E. P. Thompson to Think About South African History - Notes on A Personal Journey. Social History, v. 45, n. 4, p. 412-426, 2020; MURRAY, op. cit.

14 Nas palavras de Luise White: "Thompson estava no ar que os historiadores africanos respiravam. As suas ideias foram enfeixadas em nossos trabalhos nos anos 1970 e nos anos que se seguiram, mesmo se as referências não estivessem." Cf. WHITE, L. Whigs and Hunters: the Path not Taken. Journal of African History, v. 58, n. 1, 2017, p. 58-59.

15 Cf. BARRETT, J. R. Making and Unmaking the Working Class: E. P. Thompson and the "New Labor History" in the United States. Historical Reflections, v. 41, n. 1, p. 7-18, 2015; ICHIHASHI, H. The Reception of E. P. Thompson in Japan. International Review of Social History, v. 61, n. 1, p. 51-73, 2016; POY, L. Remaking The Making: E. P. Thompson's Reception in Argentina and the Shaping of Labor Historiography. International Review of Social History, v. 61, n. 1, p. 75-93, 2016.

16 COOPER, F. Work, Class and Empire: an African Historian's Retrospective on E. P. Thompson. Social History, v. 20 , n. 2,1995 , p. $236-237$. 


\section{A história social sul-africana dos anos 1980: emergência e conquista de hegemonia}

EM ESTUDOS que têm abordado a história da historiografia sul-africana, a emergência e a conquista de hegemonia por parte da história social (em especial, a de matriz thompsoniana) no interior da produção historiográfica local são recorrentemente explicadas, ainda que com diferentes ênfases, por quatro grandes conjuntos de elementos: 1) as conexões com tendências historiográficas internacionais então em curso; 2) o intenso diálogo (marcado por rupturas/continuidades e oposições/concordâncias) com tradições intelectuais e debates historiográficos sul-africanos; 3) significativas transformações ocorridas nas instituições universitárias de produção historiográfica sul-africanas; 4) desenvolvimentos sociopolíticos no interior da África do Sul. Abordemos, sinteticamente, cada um desses conjuntos.

\section{Tendências historiográficas internacionais}

NAÁFRICADO SUL dos anos 1960 e 1970, era bastante frequente que historiadores universitários falantes do inglês (em sua esmagadora maioria, brancos) se dirigissem a universidades estrangeiras (em especial, às britânicas) para obter seus títulos de pós-graduação, prática intensificada, em diversas ocasiões da segunda metade do século $X X$, especialmente durante as fases mais autoritárias do Apartheid, que criavam um contexto intelectual sufocante e, às vezes, ameaçador, levando muitos ao autoexílio. Nesse sentido, pelo menos três desenvolvimentos intelectuais ocorridos na Grã-Bretanha, nas mencionadas décadas, são cruciais para a emergência, na segunda metade dos anos 1970, da história social sul-africana (em particular, aquela produzida no WHW).

O mais evidente é, com certeza, a experiência do History Workshop, criado em 1966, no Ruskin College (Universidade de Oxford), por um coletivo de historiadores socialistas e feministas, que se tornou "agente fundamental da divulgação do evangelho da nova história social e do trabalho" e fez de The Making e da tradição a que pertencia uma de suas principais fontes de inspiração. ${ }^{17}$ Caracterizado, também, por sua preocupação em produzir uma história pública que dialogasse com as experiências da classe trabalhadora, o History Workshop britânico foi uma referência decisiva para personagens como Belinda Bozzoli, cientista social sul-africana amplamente reconhecida como a figura mais dinâmica na organização institucional e na produção intelectual do WHW em sua primeira década de existência. ${ }^{18}$

17 DWORKIN, D. E. P. Thompson - historiador militante, militante historiador. História e Perspectivas, Edição Especial E. P. Thompson, 2014, p. 102-103.

18 Ela foi, por exemplo, a organizadora das publicações das coletâneas de artigos selecionados dos três primeiros congressos trienais organizados pelo WHW $(1978,1981$ e 1984), sendo, também, a autora das introduções dos mencionados livros, as quais são consideradas por importantes membros do WHW (e, também, pelos críticos da organização) como verdadeiros manifestos da instituição. Cf. BONNER, P. Keynote Address to the Life after Thirty Colloquium (History Workshop). African Studies, v. 69, n. 1, 2010, p. 15-18. 
O segundo desenvolvimento intelectual do contexto britânico que veio a ter importantes repercussões sobre os historiadores sociais sul-africanos foi o conjunto de debates no interior da tradição marxista inglesa, particularmente aqueles travados entre membros da New Left. Surgida na segunda metade dos anos 1950, a New Left inglesa se viu em profundas tensões internas já em meados da década seguinte. Nessa ocasião, um novo conjunto de intelectuais assumiu a direção da New Left Review, estabelecendo uma série de rupturas com as orientações precedentes da publicação e delineando uma transição dotada de, pelo menos, três dimensões: geracional, política e teórica. Em relação a este último aspecto, vale mencionar que, na medida em que identificava uma falta de rigor teórico na produção marxista britânica vigente, a nova geração da New Left buscava introduzir, a partir de meados dos anos 1960, conceitos elaborados por intelectuais marxistas continentais. ${ }^{19}$ Entre esses, destacou-se o filósofo francês Louis Althusser, cuja obra veio a ser vista por E. P. Thompson como a principal matriz dos estruturalismos que passaram a povoar as ciências humanas e sociais britânicas nos anos 1960 e 1970, quadro contra o qual ele veio a se opor de maneira virulenta por meio de seu The Poverty of Theory, publicado em 1978. ${ }^{20}$ Para muitos historiadores vinculados ao WHW, esse clássico thompsoniano veio a se tornar uma leitura impactante e indispensável em suas próprias disputas políticas e teórico-metodológicas. ${ }^{21}$

Por fim, no entendimento da emergência da história social sul-africana, é impossível não mencionar as profundas transformações experimentadas pelo africanismo britânico a partir de princípios dos anos 1970, particularmente daquele elaborado na School of Oriental and African Studies (SOAS), sediada na University of London. Nessa instituição, sob a destacada influência da sul-africana Shula Marks, diversos pesquisadores da África do Sul realizaram seus mestrados e doutorados marcados por aquilo que alguns batizaram de "africanismo desencantado". ${ }^{22}$ Tal denominação buscava dar conta do refluxo do enorme otimismo que, na segunda metade dos anos 1950 e nos anos 1960, contagiou muitos intelectuais diante da conquista da emancipação política por diversos países africanos. No fim da década de 1960 e ao longo da seguinte, dificuldades em se superar obstáculos ao desenvolvimento econômico, soluções políticas autoritárias e guerras civis que proliferavam em vários dos recém-estabelecidos Estados-nações africanos levaram muitos intelectuais a uma desilusão com suas próprias expectativas precedentes. Para alguns deles, contudo, esse novo contexto estimulou uma série de reflexões que renovariam o africanismo, estabelecendo-se uma forte desconfiança em relação a discursos nacionalistas e um amplo interesse em se investigar a fundo as particularidades das dinâmicas do capitalismo e da luta de classes no continente africano. Ao mesmo tempo, acentuava-se, nessa nova geração de africanistas, algo já

19 Cf. DALAQUA, R. H. O debate no interior da New Left britânica: o significado da controvérsia entre Perry Anderson e E. P. Thompson. História Social, n. 16, 2009, p. 225-231.

20 MACEDO, F. B. O (re)fazer-se da historiografia: a obra de E. P. Thompson na produção discente do PPGH da Unicamp (1982-2002). Tese (Doutorado) - FFLCH-USP, São Paulo, 2017. p. 96-108.

21 Cf., por exemplo, GLASER, op. cit., p. 436.

22 Cf. BONNER, op. cit., 2010, p. 14. 
presente na anterior: a crença de que os problemas por eles analisados somente seriam adequadamente compreendidos por meio de uma perspectiva interdisciplinar, alargando, assim, os canais para intercâmbios entre historiadores, sociólogos, antropólogos, cientistas políticos, economistas etc. "Africanismo desencantado" ${ }^{23}$ e interdisciplinaridade ${ }^{24}$ foram componentes centrais na formação de importantes intelectuais do WHW, vindo alguns deles, como Philip Bonner e Peter Delius, a liderar o comitê executivo da instituição por muitos anos consecutivos.

\section{Tradições intelectuais e debates historiográficos sul-africanos}

EVIDENTEMENTE, para ser relevante no contexto historiográfico sul-africano, a nova história social tinha que, obrigatoriamente, dialogar (ainda que para marcar distanciamentos e rupturas) com tradições e produções intelectuais acadêmicas (e até mesmo não acadêmicas) que, nas décadas anteriores, haviam estabelecido temas, problemas, teses, métodos, fontes e conceitos que informavam, em meados dos anos 1970, importantes concepções vigentes sobre a história da África do Sul.

Embora fossem elaborados, fundamentalmente, fora de instituições universitárias de produção historiográfica, dois conjuntos de formulações sobre o passado sul-africano não poderiam ser ignorados pela nova história social, a qual, às vezes, teve que se dirigir explicitamente a escritos dessas tradições. O primeiro desses conjuntos é a "tradição historiográfica nacionalista negra”, ${ }^{25}$ cujas poucas obras - escritas a partir de fins do século XIX por autores negros que, muito raramente, tinham treinamento profissional como historiadores - caracterizam-se por uma abordagem humanista-liberal cristã, fruto da educação recebida em escolas missionárias por seus autores. Ainda que estes, em sua maioria, não adotassem uma crítica radical ao imperialismo, eles tiveram o importante papel de escrever uma história centrada na população negra, oferecendo a esta um senso de identidade e incentivos para a luta por direitos iguais (como o de votar) e constituindo uma descrição, a partir de dentro,

23 Vale acrescentar que, do ponto vista metodológico, os africanistas trarão para a história social sul-africana uma enorme abertura em relação à história oral, visto que, desde os anos 1960, eles já estavam habituados, em seu campo de estudos, com os debates sobre a utilização de tradições orais africanas como fontes. Não surpreendentemente, o primeiro projeto de história oral do país foi estabelecido, em 1979, no African Studies Institute, situado em Wits. Cf. HAUSSE, P. Oral History and South African Historians. Radical History Review, n. 46-47, 1990, p. 346-347 e 350-351.

$24 \mathrm{O} W H W$ foi o primeiro programa de pesquisa interdisciplinar nas ciências humanas e sociais de Wits. Nesse cenário plural, a interface com a História mostrou-se um traço constante entre os praticantes das variadas disciplinas. Cf. POSEL, op. cit., 2010, p. 31. Tentando explicar esse quadro, B. Freund afirma que: "Uma segunda característica distintiva dos historiadores radicais na África do Sul tem sido a dificuldade de traçar fronteiras entre a história e outras disciplinas. (...) Essa falta de limites reflete a relativa fraqueza da profissão [de historiador] como um empreendimento intelectual específico, mas pode-se dizer que os historiadores têm se enriquecido pelo contato com outros intelectuais." Cf. Radical History Writing and the South African Context. South African Historical Journal, v. 24, n. 1, 1991, p. 156-157. A enorme interdisciplinaridade existente na história social sul-africana dos anos 1980 é ressaltada, também, em: SAKAR, S. Labour History in India and South Africa: Some Affinities and Contrast. African Studies, v. 66, n. 2-3, p. 181-200, 2007.

25 Cf. VISSER, W. Trends in South African Historiography and the Present State of Historical Research. Paper Presented at the Nordic Africa Institute, Uppsala (Sweden), 2004, p. 9-10. Disponível em: https://bit.ly/3xAx6M2. Acesso em: 10 ago. 2019. 
de importantes aspectos das condições de vida da população negra sul-africana (incluindo relatos sobre expropriação e resistência). ${ }^{26} \mathrm{Na}$ segunda metade do século $\mathrm{XX}$, uma nova onda da "historiografia nacionalista negra" adotaria, no embate contra o Apartheid, tons mais críticos em relação ao imperialismo e uma concepção largamente positiva (e até mesmo idealizada) das sociedades africanas pré-coloniais, assumindo o propósito de fomentar a luta de libertação. ${ }^{27}$

O segundo conjunto de escritos elaborados fora das instituições universitárias de produção historiográfica, mas que não poderiam ser completamente desconsiderados pelos novos historiadores sociais sul-africanos, pode ser agrupado sob o genérico rótulo de história radical não acadêmica. ${ }^{28}$ Embora essa denominação se refira a vertentes com grandes diferenças entre si, ela permite reunir trabalhos que partilhavam a adoção de pressupostos materialistas e de uma concepção anticapitalista. Uma das linhagens mais importantes dessa produção é aquela composta pelas obras escritas por autores, fundamentalmente brancos, vinculados ao Communist Party of South Africa (fundado em 1921 e renomeado, em 1953, para South African Communist Party). ${ }^{29}$ Nesses trabalhos, sobressai-se uma crítica radical ao capitalismo e ao imperialismo com forte ênfase na exploração e opressão sofridas pela população negra sul-africana. ${ }^{30}$ Outra significativa linhagem de produção materialista que, inspirada no trotskismo, desenvolveu-se em oposição ao partido comunista local é composta pelos escritos elaborados por autores filiados ao Non-European Unity Movement (NEUM), no qual predominavam intelectuais brancos de esquerda e membros da comunidade coloured ${ }^{\beta 1}$ da Cidade do Cabo. Tal tradição negava qualquer centralidade à raça na análise da sociedade sul-africana e mostravase, profundamente, crítica em relação a concepções liberais e nacionalistas. ${ }^{32}$

26 Excelente exemplo dessa linhagem historiográfica é Solomon Plaatje, membro fundador e primeiro secretáriogeral do African National Congress (ANC), criado em 1912, que publicou, em 1916, Native Life in South Africa. Outras duas importantes obras são: MOLEMA, S. M. The Bantu: Past and Present - An Ethnographical \& Historical Study of the Native Races of South Africa (Edinburgh, 1920) e SOGA, J. H. The South-Eastern Bantu (Johannesburg, 1930).

27 Entres outros, podem ser mencionados: NGUBANE, J. K. An African Explains Apartheid (London, 1963) e MBEKI, G. South Africa: The Peasant's Revolt (London, 1964). Em razão dos obstáculos enfrentados pela população negra para acessar o ensino universitário (e, portanto, cursos como História), a autoria negra mostrou-se, durante o Apartheid, muito mais prolífica no campo literário (prosa, poesia e produção teatral).

28 Apesar de largamente utilizado nos estudos historiográficos sul-africanos, o adjetivo "radical" (em expressões como "historiografia radical") é pouco discutido. Tomando como referência um artigo muito citado, escrito por dois expoentes do WHW, pode-se inferir que a "historiografia radical" é definida por um conjunto de temas e problemas (frequentemente associados à historiografia de esquerda), tais como: contradições do desenvolvimento capitalista, luta de classes, formas de dominação, o papel do Estado no desenvolvimento capitalista e no exercício do poder pelas classes dominantes. Cf. BOZZOLI, B. and DELIUS, P. Radical History and South African Society. Radical History Review, n. 46-47, 1990, p. 13 e 36 (Nota 1).

29 São alguns exemplos: ANDREWS, B. Class Struggles in South Africa (Cape Town, 1940); ROUX, E. Time Longer than Rope: A History of the Black Man's Struggle for Freedom in South Africa (London, 1948) e SIMON, H. J. and SIMON, R. S. Class and Colour in South Africa: 1850-1950 (London, 1969).

30 Em termos teóricos, a doutrina do SACP estava organizada, nos anos 1970 e 1980, em torno de duas formulações básica: 1) havia, na África do Sul, um "colonialismo de tipo especial" (também chamado de "colonialismo interno"); 2) concebia-se a revolução sul-africana a partir da "teoria de dois estágios": primeiro, uma revolução nacionalista negra, visto que ainda não haveria consciência de classe entre os trabalhadores sul-africanos; depois, seria construída a revolução socialista. Cf. NASH, op. cit., p. 76.

31 "Coloured" é uma categoria ainda utilizada na África do Sul (inclusive pelo Estado na realização de censos populacionais) para designar, fundamentalmente, os mestiços de brancos e negros.

32 BOZZOLI and DELIUS, op. cit., p. 15. Dois exemplos sempre mencionados dessa produção são: "Mnguni" (pseudônimo usado por Hosea Jaffe) em Three Hundred Years: A History of South Africa (1952) e "Nosipho 
No âmbito das instituições universitárias de produção historiográfica sul-africanas, duas correntes intelectuais impuseram-se como as principais interlocutoras da nova história social, ${ }^{33}$ particularmente daquela elaborada no interior do WHW. A historiografia liberal foi, repetidamente, apontada como a grande adversária a ser vencida. Já as diversas vertentes de marxismos estruturalistas foram vistas de maneira ambivalente, devendo alguns de seus aspectos centrais serem mantidos e outros superados (e mesmo abertamente combatidos). A ambiguidade da relação dos historiadores sociais com essa última corrente revela-se, por exemplo, no fato de que, nos estudos historiográficos sul-africanos, os dois agrupamentos, apesar de suas importantes diferenças, são denominados, em diversas ocasiões, por um mesmo rótulo ("historiografia revisionista", "historiografia radical", "neomarxistas" etc.). Antes de esmiuçar essa complexa relação, olhemos mais de perto a produção liberal.

Estabelecida nas primeiras décadas do século XX e tendo como seus fundadores W. M. Macmillan e C. W. de Kiewiet, a historiografia liberal tornou-se hegemônica nas universidades sul-africanas de tradição britânica em que predominavam os falantes do inglês, atingindo o seu ápice no começo dos anos 1970 com a publicação dos dois volumes da Oxford History of South Africa (editados por Leonard Thompson e Monica Wilson), expressão máxima do que alguns denominam "africanismo liberal" ${ }^{4}$ dos anos 1960, primeiro deslocamento significativo rumo a uma abordagem afrocêntrica nas instituições universitárias de produção historiográficas da África do Sul. ${ }^{35}$ Desconfiada de conceitos e teorias totalizantes e valorizando fortemente a evidência empírica, a historiografia liberal centrava-se no indivíduo no interior de seu contexto particular, enfatizando personagens importantes e suas contribuições para a configuração dos processos históricos, o que resultava em uma ampla produção sobre história política (em especial: leis, instituições e relações internacionais). Questões relativas ao desenvolvimento do capitalismo e aos seus impactos na África do Sul recebiam pouca consideração. Classe e conflito de classe não integravam o arcabouço analítico da historiografia liberal. O imperialismo, por sua vez, era caracterizado como um fenômeno fundamentalmente positivo. Por fim, outro ponto definidor dessa produção era o entendimento que ela apresentava sobre o papel de raça/

Majeke" (pseudônimo usado por Dora Taylor) em The Role of the Missionaries in Conquest (1953).

33 Nos anos 1970, havia, ainda, nas instituições universitárias de produção historiográfica sul-africanas, uma terceira corrente bastante expressiva: a historiografia africâner. Escrita, predominantemente, na língua dos descendentes de holandeses que se estabeleceram no sul da África a partir do século XVII, essa produção concentrava-se nas universidades em que havia predomínio dos africâneres, a minoria étnica decisiva para a institucionalização do Apartheid a partir de meados do século XX. A historiografia africâner era hegemonizada por uma vertente nacionalista, na qual raça tinha um papel crucial na interpretação da história do povo africâner e de suas lutas contra o imperialismo britânico e contra as "tribos africanas hostis". Em razão das características da historiografia africâner, a produção da nova história social sul-africana - esmagadoramente, escrita em inglês - tendeu a tomá-la mais como um conjunto de mitificações do que uma adversária no campo historiográfico. Para uma visão geral da historiografia africâner, cf. Cap. 3 ("Afrikaans historiography") de SMITH, K. The Changing Past: Trends in South African Historical Writing. Athens, Ohio: Ohio University, 1989 , p. $57-102$.

34 Para a breve síntese da historiografia liberal aqui apresentada, cf. as partes 2 e 4 da obra SAUNDERS, C. The Making of The South African Past: Major Historians on Race and Class. Cape Town: David Philip, 1988, p. 47-101 e 143-161 (respectivamente).

35 Basicamente, o mencionado "afrocentrismo" se desdobrou em um forte estímulo à pesquisa sobre a história pré-colonial e em uma ênfase na centralidade da ação africana para a constituição dos fenômenos sociais (no passado e no presente). 
racismo na constituição dos processos sociais locais. Na historiografia liberal, raça era vista como o elemento propulsor subjacente da história sul-africana. As configurações passadas e presente da sociedade eram explicadas em termos de raça e etnicidade. O racismo, cujas raízes se situariam no mundo pré-industrial, era entendido como "preconceito irracional" e apontado como responsável pelas práticas de discriminação e pelo Apartheid. Além disso, o racismo era visto pelos liberais como disfuncional ao desenvolvimento capitalista na África do Sul, país que manteria, de modo deletério, uma economia dual, composta de reservas rurais atrasadas e de um setor capitalista avançado. Do ponto de vista liberal, contudo, a modernização capitalista, com suas supostas tendências inerentes de racionalismo e eficiência, teria o potencial de encorajar interação e integração entre grupos raciais e, finalmente, destruir as práticas de discriminação e o próprio Apartheid. Embora as linhas gerais dessa caracterização da historiografia liberal sejam amplamente aceitas nos estudos historiográficos sul-africanos, há autores que procuram relativizar alguns de seus aspectos, ressaltando, por exemplo, que os fundadores da historiografia liberal deram bastante atenção a temas socioeconômicos (particularmente, à pobreza entre brancos e negros) e afirmaram, explicitamente, que a história da África do Sul deveria abarcar toda a sua população, declaração que, contudo, não levou tais pesquisadores a estudar sistematicamente as sociedades negras do país (algo somente realizado pelos herdeiros da mencionada corrente na década de 1960). ${ }^{36} \mathrm{Em}$ que pesem tais limitações e o recorrente antagonismo com a historiografia liberal por parte dos novos historiadores sociais, estes incorporaram importantes trabalhos daquela (particularmente pesquisas realizadas nos anos 1920 e 1930) em suas próprias investigações. ${ }^{37}$

Como mencionado anteriormente, outra corrente estabelecida nas instituições universitárias de produção historiográfica sul-africanas nos anos 1970 (ainda que não desfrutando da hegemonia dos liberais) era aquela composta por distintas variantes de marxismos estruturalistas. ${ }^{38}$ Tal corrente emergiu no fim dos anos 1960 e, nos anos seguintes, arrebatou significativo contingente de pesquisadores que, na obtenção de seus mestrados e doutorados - basicamente na Grã-Bretanha - debruçavam-se sobre o passado e o presente da sociedade sul-africana. Para tais estudiosos, o contexto dos anos 1960 na África do Sul, marcado por violenta repressão estatal, crescimento econômico acelerado e expansão/ intensificação das políticas segregacionistas do Apartheid, havia demonstrado que a tese do "capitalismo benéfico", central na historiografia liberal, não se sustentava. Isto é, a ideia de que Apartheid derivaria de um preconceito "irracional" e que o racismo, entendido como disfuncional

36 BUNDY, C. An Image of Its Own Past? - Towards a Comparison of American and South African Historiography. Radical History Review, n. 46-47, 1990, p. 123-124.

37 BOZZOLI and DELIUS, op. cit., p. 15-16.

38 Alguns textos clássicos dessa corrente são:TRAPIDO, S. South Africa in a Comparative Study of Industrialisation. Journal of Development Studies, n. 7, p. 309-320, 1971; WOLPE, H. Capitalism and Cheap Labour Power: From Segregation to Apartheid. Economy and Society, v. 1, n. 4, p. 425-456, 1972; LEGASSICK, M. The Dynamics of Modernisation in South Africa. Journal of African History, n. 13, p.145-150, 1972; MORRIS, M. L. The Development of Capitalism in South African Agriculture. Economy and Society, v. 5, n. 3, p. 292-343, 1976; JOHNSTONE, R. Class Race and Gold: A Study of Class Relations and Discrimination in South Africa. London: Routledge and Kegan Paul, 1976. 
ao desenvolvimento econômico sul-africano, enfraquecer-se-ia diante do avanço capitalista mostrava-se insustentável diante do que se testemunhava no país naquele momento. ${ }^{39}$ Nesse sentido, na análise de classe formulada pelos marxistas estruturalistas, ${ }^{40}$ adotava-se a tese oposta: as políticas de discriminação/segregação racial eram funcionais ao desenvolvimento capitalista sul-africano. Antes que uma causa, o racismo era entendido como um efeito das relações de classe sul-africanas. Haveria, na África do Sul, um "capitalismo racialmente estruturado" (ou "capitalismo racial"), o qual se baseava na superexploração da força de trabalho da população negra. Assim, as políticas de discriminação racial (e, posteriormente, o regime do Apartheid) deveriam ser explicadas não como simples persistência de antigas atitudes raciais (forjadas, como diziam os liberais, em disputas territoriais entre populações brancas e negras particularmente ao longo do século XIX), mas em função das necessidades específicas do processo de industrialização sul-africana a partir de fins do século XIX. A ampla demanda de trabalho barato por parte da indústria mineradora, por exemplo, seria a principal responsável por criar as particularidades do sistema racial sul-africano. O capital conservava, instrumentalizava e ampliava as práticas discriminatórias e segregacionistas que eram centrais para sua lógica de acumulação. Elementos cruciais do sistema de segregação racial (a formação de áreas rurais reservadas para a população negra, o sistema de trabalho baseado na migração masculina periódica, as restrições raciais ao acesso a certas profissões na indústria, o subdesenvolvimento das reservas e das terras agricultáveis de africanos) passaram a ser vistos não mais como resultado do "atraso" africano ou do preconceito racial dos brancos, mas como fenômenos produzidos, especialmente, em razão da incessante demanda da indústria mineradora por trabalho abundante e barato. Amplamente influenciados por autores como Althusser, Balibar e Poulantzas, os marxistas estruturalistas sul-africanos buscaram produzir uma análise de classe sistemática, recusando abertamente métodos empiristas e afirmando que o conhecimento somente poderia ser alcançado por meio de proposições teóricas que seriam desenvolvidas, fundamentalmente, por meio de raciocínio dedutivo. Para as diversas variantes de marxismos estruturalistas, não havia dúvida de que, mais do que raça, o processo de acumulação capitalista era a força orientadora dos principais processos de transformação na sociedade sul-africana. Por isso, a necessidade de estudos acurados sobre as relações de produção, a luta de classes e o Estado (visto, essencialmente, como um instrumento de dominação manejado por diferentes frações de capitalistas que o hegemonizavam em distintos momentos).

O embate entre liberais e marxistas estruturalistas ficou conhecido, nos estudos historiográficos sul-africanos, como "debate raça vs classe". ${ }^{41}$ Nessa disputa, não há dúvida

39 POSEL, D. Rethinking the "Race-Class Debate" in South African Historiography. Social Dynamics, v. 9, n. 1, 1983, p. 52. Segundo a autora, o crescimento econômico sul-africano dos anos 1960 só foi inferior ao do Japão.

40 Quando não indicado por nota de rodapé específica, o que se segue é uma síntese de JOHNSTONE, F. A. "Most Painful to Our Hearts": South Africa through the Eyes of The New School. Canadian Journal of African Studies, v. 16, n. 1, p. 5-26. 1982.

41 Para uma crítica liberal das formulações das vertentes marxistas estruturalistas, cf. KANTOR, B. S.; KENNY, 
de que, na segunda metade dos anos 1970, a nova história social sul-africana colocou-se no polo da análise de classes, incorporando aspectos centrais da produção precedente. Contudo, na década seguinte, a nova corrente emergente se mostraria profundamente crítica em relação a elementos cruciais das abordagens marxistas estruturalistas (às vezes, tachadas de funcionalistas e reducionistas) e procuraria desenvolver uma análise atenta às inter-relações históricas concretas entre classe e raça, como veremos mais adiante. Por ora, analisemos as mudanças nas instituições universitárias de produção historiográfica sul-africanas que tornaram possível a emergência da nova história social no país.

\section{Mudanças nas instituições universitárias de produção historiográfica sul-africanas}

DURANTE O BOOM ECONÔMICO sul-africano dos anos 1960 e em parte da década subsequente, o sistema universitário local experimentou uma notável expansão, fomentando a contratação de novos docentes e desorganizando, até mesmo pela rapidez e escala do processo, grupos de poder longamente estabelecidos nas instituições universitárias de produção historiográfica do país. ${ }^{42}$ Nesse mesmo período, houve também, em escala mundial, um rápido crescimento do campo de estudos genericamente denominado de "africanismo", fenômeno bastante alimentado pela multiplicação de Estados-nações recém-criados no continente. ${ }^{43} \mathrm{~A}$ confluência desses movimentos permitiu que uma nova geração de intelectuais sul-africanos, particularmente aqueles formados nos marcos do "africanismo desencantado" de importantes instituições britânicas, viesse a ocupar, mais intensamente ao longo dos anos 1970, significativos postos nas universidades do país. Ainda que dispersos por vários departamentos, esses estudiosos procuraram se congregar para levar adiante novas abordagens sobre o passado sul-africano, sendo o caso do WHW o exemplo mais exitoso desse tipo de movimentação, dado o protagonismo que veio a exercer no campo da história social nos anos $1980 .{ }^{44}$

Se o corpo docente das instituições universitárias de produção historiográfica passava por mudanças, o mesmo pode ser dito sobre o corpo discente, particularmente em universidades de tradição inglesa como Wits. Desde fins dos anos 1970 e aceleradamente nos anos 1980, crescia a quantidade de estudantes negros matriculados. Em uma sociedade largamente estruturada

H. F. The Poverty of Neo-Marxism: The Case of South Africa. Journal of Southern African Studies, v. 3, n. 1, p. 20-40, 1976. Para uma ácida crítica das posições de liberais e de neomarxistas a partir de um ponto de vista do nacionalismo africano, cf. MAGUBANE, B. M. Whose Memory - Whose History? - The Illusion of Liberal and Radical Historical Debates. In: H.E. Stolten (ed.). History Making and Present Day Politics. Uppsala: Nordiska Afrikainstitutet, 2007, p. 251-279.

42 BOZZOLI and DELIUS, op. cit., p. 22 e 39 (nota 37).

43 Vale lembrar que, diferentemente da maioria dos países do continente, a África do Sul desfrutava, desde 1910, de considerável autonomia político-administrativa, tendo alcançado, em 1931, mesmo ano em que passa a integrar o Commonwealth of Nations, o completo autogoverno. Acontecimentos desse tipo são frequentemente invocados para se sustentar um "excepcionalismo" sul-africano em relação aos demais países do continente. Em sentido oposto, pode-se argumentar que as especificidades sul-africanas estão profundamente enraizadas no contexto continental. O próprio recrudescimento do Apartheid nos anos 1960, por exemplo, pode ser visto como uma resposta aos novos Estados-nações liderados por negros que emergiam no continente.

HYSLOP, op. cit., p. 101-102. 
em termos de segregação racial, é digno de nota observar que, no fim dos anos 1980, cerca de um quarto dos estudantes de Wits eram negros. Entre estes, havia significativos contingentes com experiência prévia de militância política, incluindo a participação em emblemáticos eventos, como os levantes estudantis secundaristas iniciados, em 1976, em Soweto. Ao mesmo tempo, havia, também, entre os estudantes brancos de Wits uma crescente parcela inclinada ao engajamento e à radicalização política na luta contra o Apartheid. ${ }^{45}$

As mudanças nos corpos docente e discente de universidades como Wits criaram um ambiente institucional e intelectual bastante propício às novas práticas historiográficas propugnadas pela história social (em particular, a de matriz thompsoniana). A conjuntura mais ampla mostrava-se igualmente favorável, uma vez que multifacetados movimentos sociais, que pareciam encarnar a "agência" dos subalternos tão propalada pelos novos historiadores sociais, ganhavam as ruas para exigir um amplo leque de reivindicações e, no limite, pôr fim ao Apartheid.

\section{A conjuntura sociopolítica sul-africana: os anos 1970 e 1980}

No FIM DOS ANOS 1960, as principais organizações que articulavam a luta contra o Apartheid estavam destroçadas. Operando no exílio, algumas delas procuravam levar adiante ações de luta armada (especialmente, sabotagens), mas encontravam enorme dificuldades em fomentar e em se conectar com movimentos de massa no interior do país. ${ }^{46}$ Esse quadro de desesperança começou a se transformar a partir de 1973, quando um inesperado e vigoroso ciclo de greves dos metalúrgicos mobilizou expressivos contingentes de trabalhadores negros da cidade de Durban. No começo, os sindicatos independentes que emergiram dessas ações grevistas procuraram manter uma certa distância das organizações que lutavam contra o Apartheid e operavam a partir do exílio. Por um lado, os sindicalistas queriam priorizar as demandas que surgiam do chão de fábrica (salários, condições de trabalho etc.) e que haviam Ihes trazido legitimidade junto aos trabalhadores. Por outro, eles temiam que qualquer conexão com as organizações anti-Apartheid desse ao governo justificativas legais para o fechamento dos sindicatos, os quais pleiteavam seu reconhecimento oficial como representantes dos trabalhadores junto ao Estado e aos patrões. ${ }^{47}$ No fim dos anos 1970, contudo, o novo sindicalismo negro, cada vez mais fortalecido, viu-se crescentemente envolvido na luta contra o Apartheid, quadro consolidado e expandido nos anos 1980, quando a criação de uma poderosa central sindical nacional acentuou o lugar de destaque dos trabalhadores na luta contra o sistema de segregação racial. Tal papel era fortalecido, ainda, pelas mobilizações dos

45 GLASER, op. cit., p. 428-429.

46 Para a descrição que se segue, quando não indicado por notas de rodapé específicas, cf. os capítulos 11 e 12 de NATTRASS, G. A Short History of South Africa. Johannesburg: Biteback Publishing, 2017. Igualmente informativos são os sete episódios da série de documentários HAVE YOU HEARD FROM JOHANNESBURG? (Dir.: Connie Field, EUA, 2010, 510 min.).

47 TATHAM, op. cit., p. 124-125. 
trabalhadores rurais, os quais resistiam às ações de remoção forçada por parte do Apartheid, que buscava implementar políticas de realocações populacionais para territórios definidos segundo critérios étnico-raciais.

Entre a juventude, os estudantes secundaristas de Soweto protagonizaram, em 1976, uma série de manifestações, violentamente reprimidas pelo Estado, contra a educação bantu, constituída por um currículo específico que limitava as possibilidades profissionais dos jovens negros, e a obrigatoriedade do ensino em língua africâner, um dos principais símbolos da minoria branca que governava o país. Largamente inspirados pelas ideias do Black Consciousness Movement (BCM), fundado por Steve Biko na segunda metade dos anos $1960,{ }^{48}$ os protestos de Soweto logo encontrariam eco em muitas partes do país. Nos anos seguintes, participantes dos levantes estudantis, além de aderirem aos movimentos de luta armada, engrossariam os diversificados e pujantes movimentos comunitários que emergiam em todo o país (grupos de teatro, organizações para ocupação de terrenos e moradias etc.).

Em 1983, a criação do United Democratic Front (UDF), entidade que passou a articular, nacionalmente, essa extraordinária pluralidade de movimentos constituídos a partir de meados anos 1970, assinalou um novo patamar na luta pelo fim do Apartheid. Nessa ocasião, o African National Congress (partido de Nelson Mandela) e o South African Communist Party, duas das principais forças anti-Apartheid no exílio, já haviam se reconectado ao movimento de massas no interior do país, desempenhando importante papel de liderança. Para os novos historiadores sociais, o que testemunhavam no presente confirmava a sua determinação de, em sua análise do passado, ressaltar a centralidade da luta de classes e da agência dos subalternos na configuração dos processos históricos. Tais elementos, assim como alguns outros, passariam a ser vistos como distintivos da produção do WHW, a qual passamos a analisar mais detidamente na próxima seção.

\section{Principais características da produção filiada ao WHW}

QUANDO CONSIDERAMOS a produção filiada ao WHW que veio a lume ao longo dos anos 1980, três grandes temas se destacam: 1) a complexa história da penetração capitalista e da industrialização na África do Sul, o que resultou em uma notável preponderância de estudos sobre os séculos XIX e XX; 2) como os mencionados processos afetaram as vidas das pessoas nos âmbitos econômico, social, político e cultural, o que nos revela a busca por uma abordagem multidimensional e não economicista dos fenômenos humanos; 3) como as respostas das pessoas comuns a esses amplos processos modelaram, até certo ponto, a configuração e o desenvolvimento dos mesmos, o que nos indica o firme propósito de recusar explicações deterministas e de pesquisar/escrever uma "história vista de baixo".

48 Para uma discussão sobre o BCM como movimento político e intelectual, cf. ALLY, N. and ALLY, S. Critical Intellectualism: The Role of Black Consciousness in Reconfiguring the Race-Class Problematic in South Africa. In: MNGXITAMA, A. (ed.). Biko Lives! London: Palgrave Macmillan, 2008, p. 171-188. 
$\mathrm{Na}$ investigação dos três grandes temas acima apontados, alguns eixos analíticos se mostraram recorrentes na produção filiada ao $W H W$, sendo eles: a) o interesse na continuidade de elementos pré-capitalistas em contextos de acelerado desenvolvimento capitalista; b) uma forte ênfase na análise da cultura (em suas dimensões simbólicas, recreativas e organizacionais); c) uma larga utilização da categoria "comunidade", ressaltando, contudo, suas tensões internas (em particular, as raciais, as étnicas e as de classe); d) uma centralidade da análise de classes, privilegiando os processos de formação, a agência/iniciativa dos subalternos e as articulações/tensões entre classe/raça, classe/etnicidade e classe/gênero, sem descuidar, todavia, de mecanismos de controle/cooptação/hegemonia elaborados pelas classes dominantes; e) um foco nas dinâmicas do Estado, investigado, especialmente, em suas contradições e ambiguidades internas.

Assentada nos três temas e nos eixos analíticos prioritários que brevemente caracterizamos, a produção do WHW deu corpo, nos anos 1980, a uma multiplicidade de estudos que transformaram, profundamente, o entendimento sobre o passado e o presente da sociedade sul-africana e que podem ser agrupados, basicamente, em três grandes áreas: 1) história social do trabalho; 2) história social urbana e 3) história social rural. Vejamos de perto cada uma delas, salientando as inovações trazidas pela produção filiada ao WHW.

\section{História social do trabalho}

Como EM outros países do mundo, a história do trabalho foi, na África do Sul, um dos campos mais impactados pela abordagem da nova história social (especialmente, a de matriz thompsoniana), quando esta começou a ganhar terreno nas instituições universitárias de produção historiográfica sul-africanas na segunda metade dos anos $1970 .{ }^{49}$ Isso não significou, contudo, que ela tenha se tornado a única abordagem sobre o objeto. Pelo contrário, ao longo dos anos 1980, ficou cada vez mais visível a distinção entre uma história do trabalho, produzida, fundamentalmente, por sociólogos e centrada nas relações industriais, nos locais de trabalho e nas organizações da classe trabalhadora e uma história social do trabalho, elaborada, em larga medida, por historiadores e interessada em enfocar a vida da classe trabalhadora e a de outros grupos oprimidos fora dos locais de trabalho, ressaltando as pluralidades das formas de vida e de consciência. ${ }^{50} \mathrm{Em}$ que pese essa distinção, a história do trabalho dos anos 1970 produziu uma série de pesquisas que se mostraram incontornáveis para os historiadores sociais. ${ }^{51}$ Como lembra Philip Bonner, um dos fundadores do WHW, não deve ser visto como acaso o fato de que a criação da instituição tenha se dado logo após a

49 Quando não indicado por nota de rodapé específica, o que se segue é uma síntese do Cap. 4 ("The History Workshop, Labour History and Social History") de TATHAM, op. cit., p. 123-149.

50 Cf. LEWIS, J. South African Labor History: A Historiographical Assessment. Radical History Review, n. 4647, 1990, pp. 213-235.

51 Cf. FREUND, B. Labour Studies and Labour History in South Africa: Perspectives from the Apartheid Era and After. International Review of Social History, v. 58, n. 3, p. 493-519, 2013. 
Wits Labour History Conference, que, realizada em 1976, congregou pesquisadores de todo o país interessados na temática do trabalho e pôs em contato aqueles que buscavam imprimir uma abordagem social ao objeto. ${ }^{52}$

Em um contexto marcado pela ascensão das lutas das organizações operárias, os anos 1970 caracterizaram-se, na África do Sul, por uma intensificação do interesse acadêmico pelo tema do trabalho, o que resultou na criação de instituições que aproximavam estudiosos dos sindicatos ${ }^{53}$ e na proliferação da publicação de pesquisas sobre o tema. ${ }^{54}$ Ainda que a maioria dessas investigações apresentasse as características do que acima descrevemos, segundo a denominação mais frequente nos estudos historiográficos sul-africanos, como "história do trabalho" (com acentuada presença de abordagens estruturais baseadas em economia política), obras em que são notáveis aspectos centrais da história social já começam a se destacar a partir de meados dos anos $1970 .{ }^{55}$ Certamente, essa tendência foi impulsionada e acelerada pelo ciclo de greves iniciado em 1973, que, contrariando a imagem de passividade e subserviência operárias da década anterior, ampliou, entre intelectuais sul-africanos, a percepção da agência dos trabalhadores e a crença de que estes poderiam ser sujeitos fundamentais das transformações no país. Para muitos desses pesquisadores, ganhava força o entendimento de que a adequada compreensão da consciência dos trabalhadores exigia estudos das comunidades em que eles viviam, o que dava novo ímpeto à utilização da metodologia da história oral, a qual já vinha sendo empregada para explorar as experiências dos operários em seus locais de trabalho. ${ }^{56}$ Apontando, igualmente, em direção à história social, já se notam, na segunda metade dos anos 1970, pesquisas que buscam incorporar em suas análises não apenas os militantes comuns dos sindicatos, mas também os trabalhadores não sindicalizados, juntamente com as formas não institucionalizadas de luta e de resistência.

Embora não descuidasse de questões como a composição da força de trabalho, o desenvolvimento econômico, a organização dos trabalhadores e as estruturas de controle e

52 Cf. BONNER, op. cit., 2010, p. 15. Deve-se lembrar, por exemplo, que P. Kallaway e E. Webster, que viriam a compor o comitê diretivo do WHW, assim como Bonner, não apenas participaram do mencionado congresso de 1976, mas foram os responsáveis por sua organização.

53 Dois bons exemplos são o Institute of Industrial Education e a Industrial and Aid Society.

54 Além dos vários artigos publicados no South African Labour Bulletin (criado em 1974), podem ser mencionados, por exemplo, BONNER, P. (ed.). Working Papers in Southern African Studies. Johannesburg: Ravan, 1977; ADLER, T (ed.). Perspectives on South Africa: A Collection of Working Papers. Johannesburg: African Studies Institute, Wits, 1977; WEBSTER, E. (ed.). Essays in Southern African Labour History. Johannesburg: Ravan, 1978.

55 Obra quase sempre apontada como um marco é ONSELEN, C. van. Chibaro: African Mine Labour in Southern Rhodesia, 1900-1933. London: Pluto Press, 1976. Segundo MURRAY, op. cit., p. 86-87: "Em Chibaro, a influência de Thompson, Hobsbawm e Rude era, de fato, notável. O tema organizador central de van Onselen o fazer-se de uma classe trabalhadora africana a partir de um mundo pré-industrial de 'obrigações tradicionais e responsabilidades' - ecoava o objetivo principal de Thompson em The Making of the English Working Class (1964). Do mesmo modo, van Onselen centrou sua análise intrigante da resposta da classe trabalhadora à exploração no que Thompson chamou de 'formas subpolíticas de resistência'."

56 Segundo E. Webster: "Para responder a essa questão [por que os trabalhadores se sindicalizavam?], era necessário seguir os trabalhadores em seus quartos nas hospedarias e nos barracos das townships, para identificar seus pertencimentos associativos, seus vínculos e parentescos e suas aldeias de origem. A prontidão dos trabalhadores em aceitar a organização coletiva e em se associar em sindicatos e outras formas de organização de trabalhadores assentava-se essencialmente nesta teia mais ampla de redes sociais." Cf. South African Labour Studies in a Global Perspective, 1973-2006. Labour, Capital and Society, v. 37, n. 1-2, 2004, p. 265-266 (grifos nossos). 
disciplina, o comitê do WHW procurou promover, em seus eventos e publicações, uma ênfase em relação à cultura, à consciência e à agência da classe trabalhadora, investigadas a partir de uma "história vista de baixo". Tal orientação levou a um crescente interesse em se explorar uma série de diferenças no interior da classe trabalhadora, tais como: raça, etnia, gênero, sexualidade e nacionalidade ${ }^{57}$ Igualmente encorajada era a atenção ao papel de continuidades pré-capitalistas na configuração de estratificações internas à classe trabalhadora e dos próprios processos de exploração. Esse conjunto de preocupações permitiu que pesquisas filiadas ao $W H W$ viessem, por exemplo, a demonstrar a centralidade de redes sociais construídas no mundo rural para a organização dos processos de migração, de reassentamento urbano e de construção de hierarquias/divisões nos locais de trabalho situados nas cidades.

Diferentemente do que preponderava nos estudos anteriores sobre trabalho, o WHW buscou promover investigações que fossem além dos trabalhadores da mineração, principal atividade econômica na região de Witwatersrand. Com isso, alargou-se o caminho para pesquisas sobre diversos outros setores industriais, o trabalho doméstico, os mais variados tipos de atividades informais e, até mesmo, sobre a multifacetada atuação de gangues urbanas, reforçando a tendência de se pensar os trabalhadores tanto dentro quanto fora de seus locais de trabalho. Caminho similar foi trilhado com as formas de protesto, ampliando-se o foco quase exclusivo em greves organizadas por sindicatos ou em movimentos articulados a partir dos locais de trabalho para abarcar, também, boicotes, paralisações no setor de transportes, ações de luta por moradia e mobilizações variadas em torno do nacionalismo cultural (especialmente, o negro).

Ao longo dos anos 1980, os estudos dedicados à temática do trabalho foram perdendo espaço na produção filiada ao $W H W{ }^{58}$ Se, no congresso de 1978 , metade dos seminários relacionava-se com o mencionado tema, no evento de 1987, eles já estavam reduzidos a um quarto. Em sentido inverso, testemunhou-se, no mesmo período, um extraordinário crescimento de pesquisas relacionadas à história social urbana. Dentro do próprio comitê diretivo do WHW, essa mudança de rumos também ficou assinalada com a saída, em 1987, de Eddie Webster, um sociólogo do trabalho que, desde o começo dos anos 1970, mantinha fortes conexões com o mundo sindical e se mostrava especialmente interessado em relações industriais, em processos de trabalho e nas organizações dos trabalhadores. Para ele, o WHW, além de estar de deslocando de um entendimento de classe em termos de relação de

57 Ressaltando a posição, predominante entre membros do WHW, sobre as limitações de uma estreita análise de classe no caso sul-africano, uma das principais lideranças da instituição não hesitou em afirmar, no fim dos anos 1980, que: "a cultura popular não é diretamente assentada em consciência de classe. Ela é constituída, fundamentalmente, por meio de categorias tais como comunidade, região, etnia, localidade, gênero ou raça. Por uma complexa variedade de razões, somente raramente classe constitui, de fato, o elemento significativo em formações culturais. Isso não significa, é claro, negar o valor analítico de classe como um conceito, mas apenas notar que 'cultura' e 'classe' raramente são coincidentes na África do Sul”. Cf. BOZZOLI, op. cit., 1990, p. 239.

58 Para uma discussão sobre o declínio, especialmente nos anos 1990, dos estudos sobre trabalho (em diversos campos disciplinares) na África do Sul, cf. BUHLUNGU, S. South Africa: The Decline of Labour Studies and The Democratic Transition. Work and Occupations, v. 36, n. 2, p. 145-161, 2009. 
produção para uma visão mais culturalista, não mantinha um relacionamento suficientemente estruturado com as lutas e as organizações da classe trabalhadora. ${ }^{59}$

\section{História social urbana}

A ACELERADA MULTIPLICAÇÃo de estudos sobre história urbana - incluindo as investigações empreendidas a partir da abordagem da história social ${ }^{60}$ - na África do Sul dos anos 1980 é, comumente, vista como bastante relacionada ao contexto de proliferação de organizações e de mobilizações, cada vez mais visíveis a partir segunda metade dos anos 1970, que passaram a caracterizar as townships. ${ }^{61}$ Estas começaram, nos anos 1980, a ser crescentemente abordadas pelos historiadores sociais por meio da noção de "comunidade", ${ }^{2}$ o que não excluía a consideração de clivagens e de conflitos internos (baseados em classe, raça, etnia, territorialidade, gênero, religião etc.). Por fim, vale lembrar que o expressivo percentual de população urbana na África do Sul da década de 1980 (algo em torno de 50\%) estava associado a uma série de problemas (carência de aparelhos urbanos de uso coletivo, escassez de habitação, assentamentos irregulares, elevadas taxas de pobreza e de desemprego etc.) que faziam, por si só, das cidades um objeto que se impunha à reflexão dos intelectuais.

No primeiro congresso organizado pelo WHW, em 1978, a importância de temas relativos à história urbana já se esboçava, quando constatamos que eles se encaixavam em três dos oito seminários do evento. Contudo, a maioria dos papers apresentados, demonstrando a permanência de uma "história vista de cima", enfocava a legislação e a atuação estatais para controlar e administrar a vida das pessoas comuns. Mesmo quando o foco recaía sobre os protestos comunitários, prevalecia uma ênfase em organizações e em suas lideranças. Até os papers dedicados à cultura optavam por ressaltar a manipulação cultural empreendida pelos grupos dominantes e a influência da economia política na cultura. Entretanto, já a partir do congresso de 1981, é possível notar um afrouxamento das amarras economicistas e

59 Em que pese a oposição ao Apartheid ter se tornado característica fundante e definidora da atuação do WHW nos anos 1980, sempre houve discordâncias entre os participantes sobre como levar adiante esse posicionamento, o que deu margem a disputas e defecções. Alguns propugnavam por uma concepção "obreirista" e, portanto, um forte engajamento junto aos sindicatos e um horizonte revolucionário socialista. Outros defendiam uma posição "populista", o que, na África do Sul, significava uma estreita conexão com organizações nacionalistas negras, particularmente o African Nacional Congress e um horizonte político marcado pela noção de luta de libertação nacional. Por fim, havia o agrupamento dos que defendiam a ideia de independência intelectual, o que, na prática, significava apoiar a luta contra o Apartheid, mas sem se filiar explicitamente à nenhuma organização política. Cf. BOZZOLI, op. cit., 1990.

60 Quando não indicado por nota de rodapé específica, o que se segue é uma síntese do cap. 5 ("The History Workshop and Urban History") de TATHAM, op. cit., p. 150-177.

61 Nome dado às áreas urbanas segregadas reservadas à população negra sul-africana. Nos anos posteriores aos levantes estudantis de Soweto, ocorridos em 1976, as townships tornaram-se o cenário de vigorosas campanhas (nas quais se destacavam as organizações formadas por jovens) de boicote, de reivindicação de infraestrutura urbana e de reformas educacionais. Entre os próprios sindicatos, foi se tornando cada vez mais comum as articulações com organizações e ações comunitárias. Toda essa movimentação foi reforçada, ainda, pela criação do United Democratic Front, em 1983.

62 A ampliação da frequência do uso do conceito pode ser notada em três das coletâneas de artigos apresentados nos congressos organizados pelo WHW: BOZZOLI, op. cit., 1983; BOZZOLI, op. cit., 1987; BONNER, P. et al., op. cit., 1989. 
classistas nos papers dedicados a analisar a cultura dos moradores das cidades sul-africanas (expandindo-se, portanto, o foco para a além das townships). Assinalando um movimento que se consolidaria nos congressos posteriores, ${ }^{63}$ aumentava a quantidade de papers que exploravam uma ampla diversidade de bem-estabelecidas culturas urbanas assentadas em multifacetadas práticas empreendidas por pessoas comuns em suas vidas cotidianas (música, lazer, esportes, cultos religiosos, ações de caridade, crime etc.). ${ }^{64}$ Ao longo dos anos 1980, a produção filiada ao WHW, ainda que não ignorasse as tentativas de controle e de manipulação por partes das elites, enfatizava, claramente, o estudo de culturas alternativas e de oposição aos padrões hegemônicos, ressaltando a centralidade da cultura na luta de classes. O uso crescente de história oral, bem como de fontes literárias, mostrara-se decisivo para viabilizar a investigação dos novos objetos que se delineavam nos estudos de história social urbana. A produção de biografias veio a ser vista, também, como um caminho profícuo para lidar com novas e velhas questões, valorizando a experiência e a agência de pessoas comuns. A partir de meados dos anos 1980, a produção em história social urbana vinculada ao WHW mostrouse, ainda, particularmente prolífica no que tange à incorporação da análise de gênero, do papel das mulheres e da vida familiar, articulando-a ao processo de formação de classe e às dinâmicas do desenvolvimento capitalista na África do Sul, o que, em parte, resultava de deliberados esforços de membros do comitê diretivo em encorajar tais perspectivas analíticas. ${ }^{65}$

Ao longo dos anos 1980, os estudos de "comunidades" urbanas filiados ao WHW foram se tornando cada vez mais complexos. Na conformação específica assumida por tais comunidades, a ênfase na agência dos sujeitos articulava-se com a consideração de um amplo conjunto de elementos, tais como: ciclos econômicos, perspectivas de obtenção de trabalho ou de estabelecimento de atividade econômica independente, a atuação dos governos locais etc. Outra questão incontornável eram os processos de remoção forçada e de expropriação urbana levados adiante pelo Apartheid bem como as resistências dos moradores a eles e os processos de reassentamento/reconstrução dessas comunidades.

Em que pesem as notáveis realizações, graves problemas na produção de história social urbana filiada ao WHW eram perceptíveis no final da década de 1980. Um deles era a ampla predominância de estudos que enfocavam apenas um segmento racial da população urbana, não considerando a relação dele com outros segmentos raciais e não formulando

63 No congresso organizado em 1984 pelo WHW, por exemplo, cerca de dois terços dos 51 papers apresentados eram de temas relativos à história urbana.

64 Escrita por um membro do WHW que, explicitamente, afirmava suas influências thompsonianas, a obra tomada como marco e modelo da história social urbana então produzida é: ONSELEN, C. van. New Babylon, New Nineveh: Studies in the Social and Economic History of the Witwatersrand. Johannesburg: Ravan, 1982 (2 volumes). Mais amplamente, fazendo um balanço da produção dos anos 1980, J. Higginson afirma que: Seu [o de E. P. Thompson em The Making] foco explícito nas conexões entre o que os trabalhadores faziam no local de trabalho e em suas comunidades tiveram um impacto poderoso naqueles de nós que estudavam e escreviam sobre trabalhadores/as na sul da África." Cf. The Spinning Jenny and The Sorting Table: E. P. Thompson and Workers in Industrializing Europe And Southern Africa. Journal of African History, v. 58, n. 1, 2017, p. 23.

65 Cf., por exemplo, BOZZOLI, B. Marxism, Feminism and South African Studies. Journal of South African Studies, v. 9, n. 2, p. 139-171, 1983. 
objetos que abarcassem a população urbana em sua totalidade. Outra grave limitação era a carência, apesar da existência de uma miríade de pesquisas pautadas por recortes bastante específicos e pelo uso intensivo de documentação, de obras que buscassem sintetizar os principais aspectos do processo de urbanização e da vida urbana na África do Sul.

\section{História social rural}

A HISTÓRIA SOCIAL RURAL filiada ao WHW mostrou-se uma das vertentes mais prolíficas, dinâmicas e inovadoras da historiografia sul-africana dos anos $1980 .{ }^{66} \mathrm{Em}$ parte, isso se deveu ao fato de que, na década anterior, diversos marxismos estruturalistas, por meio de uma pletora de estudos, haviam tomado as transformações no mundo rural como um elemento central para explicar a configuração específica assumida pelo capitalismo na África do Sul, ${ }^{67}$ fazendo de tal problemática um eixo incontornável de investigação para os historiadores sociais em ascensão, os quais, contudo, aproximaram-se do objeto a partir de novas questões, métodos e fontes. $A$ volumosa produção sobre história social rural da África do Sul foi impulsionada, também, por historiadores que, investigando a classe trabalhadora urbana local (largamente caracterizada por migrações masculinas pendulares periódicas do campo para a cidade), concluíram que, somente por meio de estudos aprofundados sobre as origens rurais da classe, seria possível o adequado entendimento de suas formas de consciência e de luta. Tal movimento levou importantes historiadores sociais sul-africanos dos anos 1980 a incorporarem, em sua análise de classe, uma ampla diversidade de eixos analíticos (raça, etnicidade, religião, gênero, sexualidade, relações geracionais, poderes locais tradicionais, redes de parentesco, vida comunitária, rituais, simbolismos etc.), abrindo espaço para uma "virada cultural" (marcada pela permanência de aspectos centrais do marxismo) que fez da história social da África do Sul uma das pioneiras de abordagens que tardariam a se estabelecer em outras partes do mundo. ${ }^{68}$ Por fim, o boom da história social rural sul-africana contou, também, com o crescente volume e visibilidade das lutas sociais travadas no campo pela população negra, a qual resistia às políticas de remoção/ realocação forçadas e de disciplinamento implementadas pelo Apartheid nos anos 1970 e 1980.

Alguns dos mais importantes historiadores sociais sul-africanos iniciaram seus estudos sobre a história rural de seu país (com ênfase nas sociedades africanas do século XIX)

66 Quando não indicado por nota de rodapé específica, o que se segue é uma síntese do cap. 6 ("The History Workshop and Rural Social History") e do cap. 7 ("Understanding Agrarian Change") de TATHAM, op. cit., p. 178-202 e 203-245 (respectivamente).

67 Cf. BRADFORD, H. Highways, Byways and Culs-de-Sacs: The Transition to Agrarian Capitalism in Revisionist South African History. Radical History Review, n. 46-47, p. 59-88, 1990.

68 Nas palavras de S. Sparks: "Quaisquer que sejam as especificidades e limitações da abordagem thompsoniana, a investigação dos historiadores sociais sul-africanos sobre o fazer-se da classe trabalhadora africana forçouos a se confrontar com as complexidades da cultura da classe trabalhadora africana - incluindo um acerto de contas com raça e racismo, etnicidade, nacionalismo e cosmologia, e, acima de tudo, gênero e sexualidade que preencheram, nuançaram e enriqueceram a teoria do capitalismo racial, anteriormente desenvolvida pelos marxistas estruturalistas para caracterizar a relação entre Apartheid e capitalismo. Essa riqueza etnográfica possibilitou uma espécie de 'virada cultural' (...)". Cf. Introduction - Special issue on South Africa. Social History, v. 45, n. 4, 2020, p. 407-408. 
na segunda metade dos anos 1970, quando, em sua maioria, estavam na Grã-Bretanha, realizando suas pós-graduações e participando de seminários de pesquisa coordenados por Shula Marks (situada na School of Oriental and African Studies e no Institute of Commonwealth Studies) e Stanley Trapido (situado em Oxford). ${ }^{69}$ Nos anos 1980, quando muitos desses estudiosos retornaram à África do Sul, sua influência sobre a história rural mostrou-se profícua e duradoura, especialmente na produção filiada ao WHW. Neste, a busca do comitê diretivo em estimular a pesquisa sobre o mundo rural sul-africano já ficou evidente, por exemplo, no tema geral do congresso de 1981, o segundo organizado pela instituição: "Town and Countryside in the Transvaal".

Na produção filiada ao WHW, a transformação capitalista do mundo rural sul-africano era abordada a partir de uma "história vista de baixo", ressaltando-se a agência e a resistência dos subalternos e a diversidade das experiências. A instituição mostrava-se preocupada, igualmente, em encorajar pesquisas centradas em recortes locais/regionais e assentadas em ampla evidência empírica. Valendo-se intensamente de fontes orais (em particular, entrevistas de histórias de vida) e de processos judiciais, os estudos filiados ao WHW, em contraposição à produção das vertentes marxistas estruturalistas, vieram a sustentar, por exemplo, a tese de que aspectos centrais do capitalismo sul-africano (como a migração pendular periódica de populações masculinas negras do campo para a cidade) não deveriam ser vistos como fenômenos determinados apenas pelas necessidades da acumulação capitalista ou pelas políticas segregacionistas do Estado, mas também como produtos de deliberadas estratégias de resistência à proletarização por parte de comunidades rurais negras para manter elementos cruciais de seu modo de vida tradicional (acesso à terra, configurações familiares, formas de poder local, modalidades de dominação masculina etc.). Assim, o processo de formação de classe não era apresentado como um fenômeno modelado apenas por forças estruturais e ações estatais, mas também pela agência dos trabalhadores. Na verdade, mesmo aquelas, ao invés de serem vistas de modo reificado e homogêneo, eram estudadas como processos abertos e contraditórios. ${ }^{70}$ Essa nova concepção abarcou, também, os brancos do mundo rural, cujas clivagens (incluindo as de classe) receberam estudos detalhados.

A história rural, particularmente o debate sobre o estabelecimento e a consolidação do capitalismo agrário na África do Sul, constituiu-se no terreno mais virulento das disputas entre as diversas vertentes de marxismos estruturalistas e a nova história social (especialmente, a de matriz thompsoniana). Para os praticantes desta, os partidários daquelas haviam operado com

69 Essa primeira onda de estudos de história social rural sul-africana foi elaborada a partir de múltiplas influências, sendo as mais importantes: o africanismo liberal dos anos 1960, os marxismos estruturalistas sul-africanos dos anos 1970, a antropologia política britânica e a antropologia econômica marxista francesa. Consequentemente, os elementos explorados eram, também, bastante variados: as lutas por poder e recursos no interior das sociedades africanas do século XIX; a natureza do poder e os lugares e as formas de conflito em sociedades não capitalistas; as articulações de diferentes modos de produção; os variados efeitos da penetração do capitalismo em sociedades pré-capitalistas etc.

70 Cf. BRECKENRIDGE, K. Promiscuous Method: The Historiographical Effects of the Search for the Rural Origins of the Urban Working Class in South Africa. International Labor and Working-Class History, n. 65, p. 26-49, 2004. 
categorias e descrições excessivamente generalizantes que resultavam em explicações centradas em constrangimentos externos que, na prática, obliteravam a ação dos sujeitos e as especificidades sul-africanas. Estudiosos filiados ao WHW entendiam, no fim dos anos 1980 e começo dos 1990, que, adotando as práticas historiográficas que descrevemos nesta seção, eles teriam sido capazes de reformular a visão global do desenvolvimento capitalista sul-africano oferecida pelos estruturalistas, demonstrando a importância da agência humana na constituição dos fenômenos, acentuando a diversidade local de tendências supostamente gerais e o caráter contraditório e não linear das mudanças e evidenciando articulações entre elementos pré-capitalistas e capitalistas somente apreendidas por meio de investigações com ampla base empírica.

\section{Considerações finais}

EM 1990, quando foi publicada uma edição dupla do periódico estadunidense Radical History Review dedicada à "história radical" sul-africana, ${ }^{71}$ a produção do $W H W$ alcançava uma visibilidade internacional que confirmava a centralidade de que gozava no contexto historiográfico da África do Sul. Editada por duas figuras decisivas no comitê diretivo do WHW ao longo dos anos 1980, a edição especial apresentava uma imagem laudatória da trajetória da instituição sul-africana e da produção a ela filiada. Embora houvesse o reconhecimento de desafios a serem enfrentados, o futuro, para o tipo de historiografia propugnado pelo $W H W$, parecia radiante. ${ }^{72}$ Tal imagem, contudo, não tardou a ser duramente questionada, como se pode notar em ácidas resenhas dedicadas à edição especial, ${ }^{73}$ as quais antecipavam um cenário, consolidado ao longo dos anos 1990, no qual a influência dos historiadores sociais sul-africanos, particularmente os de matriz thompsoniana, sofreria considerável declínio, quadro que eles logo passaram a admitir. ${ }^{74}$ Aparentemente, à medida que ficava claro que o African National Congress (força que hegemonizara a etapa final da luta contra o Apartheid) conduziria, em um contexto fortemente impactado pelo colapso do socialismo do leste europeu, a transição de regime priorizando um projeto nacional e conciliatório e não um projeto classista, a historiografia de fortes traços marxistas produzida pelo WHW parecia encontrar significativas dificuldades para ressoar na sociedade e para recrutar novos praticantes para as suas fileiras ${ }^{75}$ criando um terreno favorável para as críticas mais variadas.

Do ponto de vista teórico-metodológico, ganhavam espaço os questionamentos de estudiosos filiados às emergentes correntes pós-estruturalistas, as quais, durante os anos

71 Radical History Review, n. 46-47, 1990.

72 Cf., especialmente, BOZZOLI and DELIUS, op. cit.; BOZZOLI, op. cit., 1990.

73 Cf., por exemplo, SAUNDERS, C. Radical History - the Wits Workshop Version - Reviewed. South African Historical Journal, v. 24, n. 1, p. 160-165, 1991; FREUND, op. cit., 1991.

74 Cf., por exemplo, BONNER, op. cit., 1994.

75 Importantes membros e aliados do WHW ressaltam esse aspecto. Cf. BONNER, P.; HYSLOP, J.; VAN DER WALT, L. Rethinking Worlds of Labour: Southern African Labour History in International Context. African Studies, n. 66, v. 2-3, 2007, p. 151; RICH, P. Is South African Radical Social History Becoming Irrelevant? South African Historical Journal, v. 31, n. 1, 1994, p. 191; NUTTALL, T.; WRIGHT, J. Exploring Beyond History with a Capital H. Current Writing, v. 10, n. 2, 1998, p. 41. 
mais intensos de luta contra o Apartheid, pouco eco encontraram na África do Sul, mas, agora, contavam com crescente apoio em suas admoestações à história social, acusada de cegueira em relação às questões de representação e poder institucional, de tratar da classe trabalhadora como audiência e não como interlocutora e de adotar um empirismo negligente e grosseiramente avesso ao engajamento teórico. ${ }^{76}$ Setores da intelligentsia radical sul-africana passaram a questionar, também, importantes aspectos das relações raciais sul-africanas que haviam sido minimizados durante a intensa luta comum contra o Apartheid nos 1980. Apontava-se, por exemplo, a ampla predominância de brancos no comitê diretivo do $W H W$ e nos próprios congressos por ele promovidos. ${ }^{77}$ Mais amplamente, os historiadores sociais viriam a ser criticados pela política racial de suas práticas profissionais (relação com os assistentes negros, falta de conhecimento das línguas africanas etc.). ${ }^{78}$ Mesmo a predominância da ênfase em classe, na história social sul-africana dos anos 1980, começou a ser vista por alguns críticos como uma maneira de evitar incômodas análises centradas em raça. ${ }^{79}$ Agravando ainda mais as tensões, a universidade sul-africana passou por profundas reformas nos anos 1990, repercutindo, no caso da historiografia acadêmica, em questionamentos sobre a necessidade do estudo da disciplina, em redução no número de professores nos departamentos e em dificuldades para atrair financiamentos, ${ }^{80}$ delineando um cenário de perda de espaço institucional da disciplina.

Apesar das previsões de terra arrasada da década de 1990, a história social sul-africana (em especial, a de matriz thompsoniana) mostrou-se capaz de se renovar e de se manter relevante no contexto da produção historiográfica local, não mais desfrutando, contudo, da hegemonia que gozara nos anos $1980 .{ }^{81}$ No que diz respeito particularmente ao WHW, o aggiornamento iniciado nos anos 1990 não significou um abandono do legado thompsoniano, o qual foi (e continua a ser) aberta e orgulhosamente reafirmado em significativas ocasiões públicas. ${ }^{82}$

Recebido em 01/05/2021

Aprovado em 31/05/2021

76 Para uma síntese das críticas pós-estruturalistas, cf. SPARKS, S. New Turks and Old Turks: The Historiographical Legacies of South African Social History. Historia, v. 58, n. 1, p. 215-239, 2013; DEACON, R. Hegemony, Essentialism and Radical History in South Africa. South African Historical Journal, v. 24, n. 1, p. 166-184, 1991; KOCK, L. People, Power and Culture and the Ethics of Historical Representation. South African Historical Journal, v. 27, p. 243-253, 1992; ROBINSON, J. (Dis)locating Historical Narrative: Writing, Space and Gender in South African Social History. South African Historical Journal, v. 30, p. 144-157, 1994; LALU, P. When was South African History ever Postcolonial? Kronos, v. 34, p. 267-281, 2008.

77 Cf. WORGER, W. White Radical History in South Africa. South African Historical Journal, v. 24, n. 1, p. 145153, 1991.

78 HYSLOP, op. cit., p. 110-111.

79 ALLY and ALLY, op. cit.

80 DU TOIT, A. The Owl of Minerva and the Ironic Fate of the Progressive Praxis of Radical Historiography in Postapartheid South Africa. Kronos, v. 36, n. 1, p. 252-265, 2010.

81 Cf. KROS, C. Considering the Legacy of Radical/Social History in South Africa. African Historical Review, v. 39, n. 1, p. 41-58, 2007.

82 Cf. https://wiser.wits.ac.za/event/history-after-ep-thompson. Acesso em: 16 jan. 2021; HYSLOP, op. cit.; LISSONI, NIEFTAGODIEN and ALLY, op. cit. 